
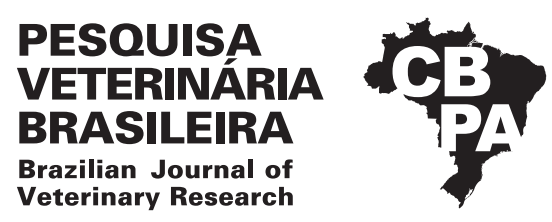

Pesq. Vet. Bras. 39(3):209-213, March 2019 DOI: $10.1590 / 1678-5150-P V B-6021$

ISSN 0100-736X (Print) ISSN 1678-5150 (Online)

\title{
Detection of avian metapneumovirus subtype A from wild birds in the State of São Paulo, Brazil ${ }^{1}$
}

\author{
Laís S. Rizotto², Raphael M. Simão², Guilherme P. Scagion ${ }^{2}$, \\ Alessandra A. Simasaki ${ }^{3}$, Leonardo C. Caserta ${ }^{4}$, Julia C. Benassi ${ }^{3}$, Clarice W. Arns ${ }^{4}$ \\ and Helena L. Ferreira ${ }^{2,3 *}$
}

\begin{abstract}
Rizotto L.S., Simão R.M., Scagion G.P., Simasaki A.A., Caserta L.C., Benassi J.C., Arns C.W. \& Ferreira H.L. 2019. Detection of avian metapneumovirus subtype A from wild birds in the State of São Paulo, Brazil. Pesquisa Veterinária Brasileira 39(3):209-213. Departamento de Medicina Veterinária, Faculdade de Zootecnia e Engenharia de Alimentos, Universidade de São Paulo, Av. Duque de Caxias Norte 225, Pirassununga, SP 13635-900, Brazil. E-mail: hlage@usp.br

The present study investigated the circulation of avian metapneumovirus (aMPV) in wild birds in Brazil. To do so, 131 samples from 366 oropharyngeal or cloacal swabs collected from 18 species of birds were tested individually or in pools by RT-PCR. Samples detected by RT-PCR were selected for DNA sequencing. Thirteen (9.9\%) samples were detected by the RT-PCR targeting the N gene and four out of 13 samples were sequenced. Sequencing results showed a high identity with the aMPV subtype A. Our results confirm the circulation of the aMPV subtype A in wild birds in Brazil even five years after its last detection.
\end{abstract}

INDEX TERMS: Detection, avian metapneumovirus, subtype A, wild birds, São Paulo, Brazil, waterfowl, surveillance, aMPV, wildlife animals, birds, viroses.

\begin{abstract}
RESUMO.- [Detecção de metapneumovirus aviário subtipo A em aves silvestres no estado de São Paulo, Brasil.] 0 presente estudo investigou a circulação de metapneumovírus aviário em aves silvestres no Brasil. Para tanto, 131 amostras de 366 suabes orofaringeanos ou cloacais coletados de 18 espécies de aves foram testadas individualmente ou na forma de pools por RT-PCR. As amostras detectadas por RT-PCR foram selecionadas para sequenciamento. Treze $(9,9 \%)$ das amostras foram detectadas por RT-PCR tendo o gene N como alvo; destas, quatro foram sequenciadas com sucesso. Resultados do sequenciamento mostraram alta identidade com o aMPV de subtipo A. Nossos resultados confirmam a
\end{abstract}

\footnotetext{
${ }^{1}$ Received on September 21, 2018.

Accepted for publication on November 9, 2018.

${ }^{2}$ Postgraduate Program in Experimental Epidemiology of Zoonoses, Faculdade de Medicina Veterinária e Ciência Animal, Universidade de São Paulo (USP), Avenida Prof. Dr. Orlando Marques de Paiva 87, Cidade Universitária, São Paulo, SP 05508-270, Brazil. *Corresponding author: hlage@usp.br

${ }^{3}$ Departamento de Medicina Veterinária, Faculdade de Zootecnia e Engenharia de Alimentos (FZEA), Universidade de São Paulo (USP), Av. Duque de Caxias Norte 225, Pirassununga, SP 13635-900, Brazil.

${ }^{4}$ Laboratório de Virologia Animal, Instituto de Biologia, Universidade de Campinas (Unicamp), Cidade Universitária Zeferino Vaz s/n, Barão Geraldo, Campinas, SP 13083-970, Brazil.
}

circulação de aMPV subtipo A em aves silvestres no Brasil mesmo cinco anos após sua última detecção.

TERMOS DE INDEXAÇÃO: Detecção, metapneumovirus aviário, subtipo A, aves silvestres, São Paulo, Brasil, aves aquáticas, epidemiologia, aMPV, animais silvestres, viroses.

\section{INTRODUCTION}

The avian metapneumovirus (aMPV; family: Pneumoviridae, genus: Metapneumovirus) (Adams et al. 2016) is divided into four subtypes (A,B,C, and D) (Juhasz \& Easton 1994, Seal 1998, Bayon-Auboyer et al. 2000). These viruses can cause respiratory disease and a drop in egg production in commercial birds, such as turkeys and chickens (Jones 1996). The aMPV viruses can also infect other birds, including pheasants, guinea fowls and wild birds (Jones \& Rautenschlein 2013). aMPV subtypes A and B have a worldwide distribution (Cook 2000), whereas aMPV C was isolate in USA, France, Korea and China from commercial birds (Seal 1998, Toquin et al. 1999, Lee et al. 2007, Sun et al. 2014). Finally, aMPV D was isolated in commercial turkeys in France (Bayon-Auboyer et al. 2000).

Wild birds seem to act as reservoirs or vectors of aMPV into poultry farms. aMPV introduction in a poultry farm by 
migrating wild birds has already been reported in the United Kingdom (Stuart 1989). In 2000, the occurrence of this disease in turkey flocks in the USA was correlated to the migration of wild birds (Shin et al. 2000). Since then, the aMPV subtype C has been isolated in the US and European countries in many avian species, such as wild ducks (Anas platyrhynchos), wild geese, wild Canada geese (Branta canadensis), and blue-winged teals (Anas discors) (Shin et al. 2000, 2002, Bennett et al. 2002, 2004, Turpin et al. 2008, Van Boheemen et al. 2012). The detection of aMPV subtype $A$ was reported in the white-cheeked pintail (Anas bahamensis), orinoco goose (Neochen jubata), white-eyed parakeet (Psittacara leucophthalmus), rusty-margined guan (Penelope superciliaris) and pigeon (Columba livia) (Felippe et al. 2011). The detection of anti-aMPV antibodies have also been reported in American coots and crows, egrets, geese, wild ducks, rock pigeons and ostriches (Cadman et al. 1994, Shin et al. 2000, 2002, Turpin et al. 2008). The present study aimed to investigate the circulation of avian metapneumovirus in wild birds in State of São Paulo.

\section{MATERIALS AND METHODS}

To achieve this goal, 366 swabs (oropharyngeal or cloacal) were collected from 192 wild birds belonging to 18 species and six different orders: Anseriformes (87.5\%), Psittaciformes (6.77\%), Columbiformes (4.17\%), Strigiformes $(0.52 \%)$, Piciformes $(0.52 \%)$ and Falconiformes $(0.52 \%)$. These swabs were collected from 2013 to 2015 at four different locations of captive birds in the São Paulo state. Swabs were tested as follows according to bird species and location: i) grouped as pools of up to five cloacal-C or oropharyngeal-OP swabs (Spackman et al. 2013); ii) grouped as pools of up to two C and OP swabs (Araujo et al. 2014); iii) tested individually. Collected swabs were stored in $500 \mu \mathrm{L}$ Brain Heart Infusion (BHI) medium containing antibiotic and anti-mycotic $(10000 \mathrm{U} / \mathrm{mL}$ of penicilin, $10000 \mu \mathrm{g} / \mathrm{mL}$ of streptomycin and $25 \mu \mathrm{g} / \mathrm{mL}$ of amphotericin B). After collection, samples were stored in $-80^{\circ} \mathrm{C}$ until processing. A total of 131 samples (Table 1) were tested. All swabs were collected according to international, national, and institutional guidelines for the care and use of animals (CEUA-FZEA-USP no. 2012.1.170.74.0, CEUA-FMVZ 5201050214 e CEUA-FMVZ-USP no. 2309251114) and legal approval of ICMBio-Brazil (SISBIO no. 3475-1).

The commercial live vaccines containing subtype A (Poulvac ${ }^{\circledR}$ TRT, Zoetis Industry) and B (Nemovac ${ }^{\circledR}$, Merial Animal Health) were used as positive controls for the RT-PCR reactions. Commercial live vaccines containing Newcastle disease virus (New-Vacin La Sota, Biovet Laboratory) and an infectious bronchitis virus (Bio-Bronk-Vet, Biovet Laboratory) were used as a specified control for the RT-PCR reactions. Viral RNA was purified from $140 \mu \mathrm{L}$ in medium of swabs using a QIAamp ${ }^{\circledR}$ RNA Mini kit (Qiagen, Hilden) according to the manufacturer's instructions.

RT-PCR targeting the N gene was done using the QIAGEN ${ }^{\circledR}$ OneStep RT-PCR kit (Qiagen, Hilden) with primers previously described by Bäyon-Auboyer et al. (1999). Briefly, reactions were tested with $2.5 \mu \mathrm{L}$ of RNA and the final concentration of 1x QIAGEN OneStep RT-PCR Buffer containing $2.5 \mathrm{mM}$ of $\mathrm{MgCl}_{2}, 1 \mu \mathrm{L}$ of enzyme mix, $400 \mu \mathrm{M}$ of each dNTP and $0.6 \mu \mathrm{M}$ of each primer and enough water to reach the final volume of $25 \mu \mathrm{L}$. Reactions were carried out in a C1000 Touch (Bio-Rad, Foster City). Briefly, the RT reaction was carried out at $50^{\circ} \mathrm{C}$ for $30 \mathrm{~min}$. PCR amplification was performed with an initial denaturation step at $95^{\circ} \mathrm{C}$ for $15 \mathrm{~min}$, followed by 40 cycles $\left(95^{\circ} \mathrm{C}\right.$ for $30 \mathrm{~s} ; 51^{\circ} \mathrm{C}$ for $30 \mathrm{~s} ; 72^{\circ} \mathrm{C}$ for $60 \mathrm{~s}$ ) and a final elongation step at $72^{\circ} \mathrm{C}$ for $5 \mathrm{~min}$. PCR products ( $115 \mathrm{bp}$ ) were visualized by electrophoresis
Table 1. Tested samples according to species, number of birds, quantity and swab types (C-cloacal or OP-oropharyngeal swabs)

\begin{tabular}{|c|c|c|c|c|}
\hline Species & $\begin{array}{l}\text { Number } \\
\text { of birds }\end{array}$ & $\mathrm{C}$ & $\mathrm{OP}$ & $\begin{array}{l}\text { Number of tested } \\
\text { samples } \\
\text { (pool/individually) }\end{array}$ \\
\hline Dendrocygna viduata ${ }^{\mathrm{a}}$ & 73 & 73 & 73 & 37 \\
\hline Aix galericulata ${ }^{\mathrm{b}, \mathrm{c}}$ & 61 & 60 & 57 & 32 \\
\hline $\begin{array}{l}\text { Dendrocygna } \\
\text { autumnalis }\end{array}$ & 10 & 10 & 10 & 5 \\
\hline Aix sponsa ${ }^{\mathrm{b}, \mathrm{c}}$ & 8 & 7 & 8 & 9 \\
\hline $\begin{array}{l}\text { Anas platyrhynchos } \\
\text { domestica }^{\mathrm{b}}\end{array}$ & 6 & 6 & 6 & 12 \\
\hline Chenonetta jubata $^{\mathrm{b}}$ & 4 & 4 & 4 & 4 \\
\hline Cairina moschata & 2 & 2 & 2 & 1 \\
\hline Dendrocygna bicolor ${ }^{\mathrm{a}}$ & 1 & 1 & 1 & 1 \\
\hline $\begin{array}{l}\text { Cereopsis } \\
\text { novahollandiae }^{c}\end{array}$ & 1 & 1 & 1 & 2 \\
\hline Cygnus melanocoryphus & 1 & 1 & 1 & 2 \\
\hline Cygnus atratus & 1 & 0 & 1 & 1 \\
\hline $\begin{array}{l}\text { Psittacara } \\
\text { leucophthalma }{ }^{\mathrm{c}, \mathrm{d}}\end{array}$ & 10 & 7 & 7 & 14 \\
\hline Ara chloropterus ${ }^{\mathrm{c}}$ & 2 & 0 & 2 & 2 \\
\hline Amazona aestiva ${ }^{\mathrm{d}}$ & 1 & 0 & 1 & 1 \\
\hline Columba livia ${ }^{\mathrm{a}}$ & 8 & 8 & 8 & 4 \\
\hline Megascops choliba $^{\mathrm{d}}$ & 1 & 0 & 1 & 1 \\
\hline Ramphastos dicolorus $^{\mathrm{d}}$ & 1 & 1 & 0 & 1 \\
\hline Falco sparverius $^{\mathrm{d}}$ & 1 & 1 & 1 & 2 \\
\hline TOTAL & 192 & 182 & 184 & 131 \\
\hline
\end{tabular}

Locations and years where samples were collected: ${ }^{a}$ Wild (migratory and resident) birds from Clube de Campo São Paulo, São Paulo/SP (2015), samples were kindly provided by Prof. Dr. Edison L. Durigon of the Laboratory of Clinical and Molecular Virology of the Institute of Biomedical Sciences (ICB-II), University of São Paulo; ${ }^{\text {b }}$ Captive birds from Commercial Bird house, Pirassununga/SP (2014); ' Captive birds from Municipal Ecological Park of Americana "Eng. Cid Almeida Franco", Americana/SP (2013); ${ }^{d}$ Wild Birds from Mata Ciliar of Jundiaí (2015), were from different origins such as smuggling, injured birds. Data about those birds is usually not available and sampling was performed upon their arrival. All birds were healthy, without any clinical signs.

using a $2 \%$ agarose gel stained with SYBR safe (Life Technologies, Carlsbad) in TBE buffer ( $\mathrm{pH}$ 8.0). A 100 bp DNA molecular ladder (Amresco, Solon) was used to estimate the band size.

Positive samples detected by RT-PCR were amplified in specific pathogen free (SPF) chicken embryonated eggs (CEE). Original samples were centrifuged at $5000 \mathrm{xg}$ for $5 \mathrm{~min}$, and $100 \mu \mathrm{L}$ was inoculated in the allantoic cavity. Eggs were observed daily for mortality for seven days. Afterwards, the allantoic fluid was collected and stored at $-80^{\circ} \mathrm{C}$. All allantoic liquids were tested by RT-PCR after three blind passages.

DNA sequencing was done to confirm positive results using the same reactions conditions described above using $10 \mu \mathrm{L}$ of RNA in the final volume of $50 \mu \mathrm{L}$. Amplicons were purified using the Illustra ${ }^{\mathrm{TM}} \mathrm{GFX}^{\mathrm{TM}}$ PCR DNA and Gel Band Purification kit (GE Healthcare, Buckinghamshire). The DNA sequencing reaction was sent to the CEGH-CEL facility (IB-USP) in duplicate along with each primer $(5 \mu \mathrm{M})$ and purified DNA (50 to $80 \mathrm{mg}$ ) for DNA sequencing. Sequencing was performed using the BigDye ${ }^{\circledR}$ Terminator v3.1 Cycle Sequencing kit (Applied Biosystems, Foster City) on an ABI 3730 DNA Analyzer (Applied Biosystems, Foster City). 
The obtained sequences were evaluated for quality using the Sequence Scanner ${ }^{\mathrm{TM}}$ Software 2 (Applied Biosystems, Foster City) and edited by MEGA7 (Kumar et al. 2016). Afterwards, the obtained sequences and sequences available in GenBank were aligned using Clustal W (Thompson et al. 1994) Bioedit Sequence Alignment software version 7.2.5 (Hall 1999). Phylogenetic analysis and tree constructions were also performed using the MEGA7 software and deduced using the Maximum Likelihood method with a total of 1000 replications on the bootstrap.

\section{RESULTS}

The RT-PCR targeting the $\mathrm{N}$ gene detected 13 positives (9.9\%) out of 131 tested samples. Eight samples were from Anseriformes (Aix sponsa, Aix galericulata, Dendrocygna viduata), three from Columbiformes (Columba livia), one from Falconiformes (Falco sparverius), and one from Psittaciformes (Psittacara leucophthalma). Five (38.4\%) samples were detected from OP swabs, four (30.8\%) detected samples from $\mathrm{C}$ swabs, and the last four (30.8\%) detected samples from cloacal and OP swabs together. Positive samples were detected in all locations; among those, three sampling sites had wild (migratory and resident) birds. The fourth sampling site, the commercial birdhouse in Pirassununga, had captive birds which also maintained poultry in this location.

Four $(30.7 \%)$ out of 13 positive samples were successfully sequenced after the first passage in CEE, although three passages were performed. Phylogenetic analysis was performed using the four samples (two from Aix galericulata, one from Dendrocygna viduata and one from Falco sparverius) based on 115 nucleotides of the $\mathrm{N}$ gene using 46 available aMPV sequences in GenBank (Fig.1). The mean genetic distance between our samples ranged from $0.0 \%$ to $0.04 \%$, showing a low genetic distance $(0.036$ to 0.049$)$ with aMPV subtype A clustering with sequences from Italy, England, Brazil, and Wales. The genetic distances of our samples with other subgroups ranged from to 0.190 to 0.238 with subtype $B, 0.218$ to 0.251 with subtype D and 0.202 to 0.268 with subtype C. A tree using larger sequences was generated before including the shorter sequences to confirm the obtained tree clusters (data not shown).

\section{DISCUSSION}

Our study detected aMPV subtype A in samples from Anseriformes, Columbiformes, Falconiformes and Psittaciformes, which is in acordance with a previous study (Felippe et al. 2011). Moreover, most positive samples were obtained from wild waterfowl which also in agreement with a recent study (Jardine et al. 2018) and previous studies (Shin et al. 2000, Bennett et al. 2002, Felippe et al. 2011, Turpin et al. 2008).

Waterfowl plays an important role in the maintenance and dissemination of several commercially important viruses, such as, AIV, NDV, including aMPV (Olsen et al. 2006, Alexander 2007, Cha et al. 2013). Wild birds seem to be highly susceptible to aMPV C (Shin et al. 2000, Bennett et al. 2004, Van Boheemen et al. 2012) and they seem to be partially susceptible to aMPV A and B (Felippe et al. 2011, Gharaibeh \& Shamoun 2012).

The virus isolation is a important tool to confirm the infection in birds. In our study, a low virus rate was detected after passage in eggs. These results suggest a limit replication

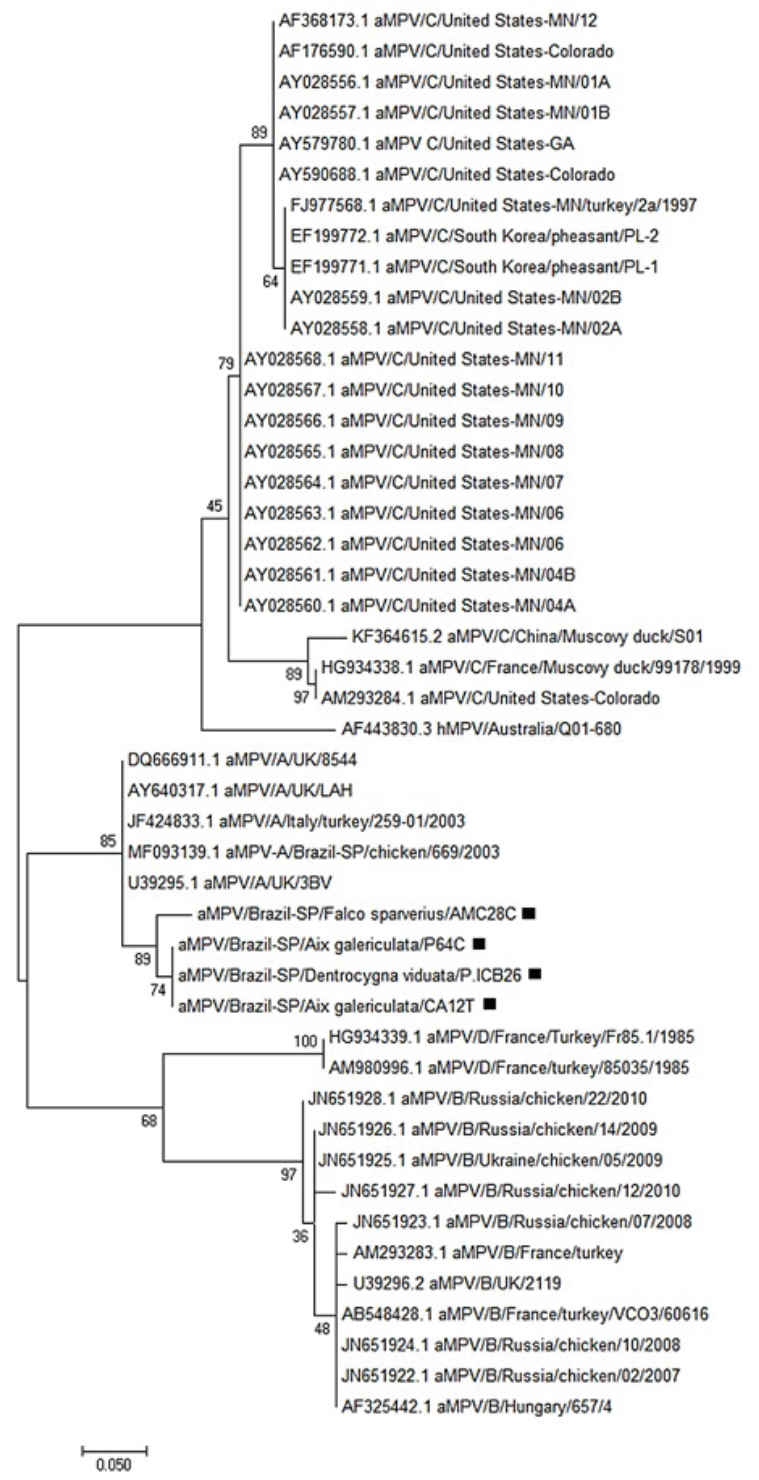

Fig.1. Phylogenetic tree of avian metapneumovirus (aMPV) samples from Aix galericulata, Dendrocygna viduata, and Falco sparverius. The evolutionary history was inferred using the Maximum Likelihood method based on the Kimura 2-parameter model (Kimura 1980). The tree with the highest log likelihood (-542.1852) is shown. The percentage of trees in which the associated taxa clustered together is shown next to the branches. The initial tree(s) for the heuristic search was obtained automatically by applying the Neighbor-Join and BioNJ algorithms to a matrix of pairwise distances estimated using the Maximum Composite Likelihood (MCL) approach, followed by selection of the topology with a superior log likelihood value. The rate variation model allowed for some sites to be evolutionarily invariable ([+I], 60.7571\% sites). The tree is drawn to scale, with branch lengths measured as the number of substitutions per site. The analysis involved 46 nucleotide sequences. The codon positions included were 1st+2nd+3rd+Noncoding. All positions with less than 95\% site coverage were eliminated. That is, fewer than 5\% alignment gaps, missing data, and ambiguous bases were allowed at any position. There were a total of 115 positions in the final dataset. Evolutionary analyses were conducted using the MEGA7 software (Kumar et al. 2016). The aMPVsequences originated from this study are denoted with a $\mathbf{a}$ symbol. 
in wild birds and it corroborates with the low rates of virus isolation already reported. A experimental study in turkeys, which is the most susceptible specie to aMPV, reported a low virus recovery rate after the 5 th day post inoculation (Cook et al. 1991). Another experimental study in pigeons showed a limit amount of virus in target tissues after infection (Catelli et al. 2012). Therefore, the limited time and replication of the virus in the tissues and excretions could explain the low rate of virus isolation from wild bird samples in chicken embryonated eggs.

\section{CONCLUSIONS}

Our study shows that aMPV subtype A continues to circulate in different wild bird species, although with very limit virus shedding, five years after the last report.

More studies are needed to investigate the role of wild birds in aMPV A epidemiology. Therefore, continuous surveillance in wild birds could be valuable in our understanding of aMPV epidemiology.

Acknowledgments.- We are especially grateful to the Biovet Laboratory and Lanagro-SP from Brazil for providing SPF CEE, and the Fundação de Amparo à Pesquisa do Estado de São Paulo (FAPESP), (grant number: 2015/11510-5), CNPq (443250/2014-6), CAPES (001) and CAPES-Newton Fund (5126-15-0). CWA and HLF are recipient of a fellowship from CNPq.

Ethical approval.- All applicable international, national, and institutional guidelines for the care and use of animals and legal approval of ICMBioBrazil were followed (CEUA-FZEA-USP no. 2012.1.170.74.0, CEUA-FMVZ 5201050214, CEUA-FMVZ-USP no. 2309251114 and SISBIO no. 3475-1).

Conflict of interest statement.- The authors declare no conflict of interest.

\section{REFERENCES}

Adams M.J., Lefkowitz E.J., King A.M., Harrach B., Harrison R.L., Knowles N.J., Kropinski A.M., Krupovic M., Kuhn J.H., Mushegian A.R., Nibert M., Sabanadzovic S., Sanfaçon H., Siddell S.G., Simmonds P., Varsani A., Zerbini F.M., Gorbalenya A.E. \& Davison A.J. 2016. Ratification vote on taxonomic proposals to the International Committee on Taxonomy of Viruses (2016). Arch. Virol. 161(10):2921-2949. <http://dx.doi.org/10.1007/s00705016-2977-6><PMid:27424026>

Alexander D.J. 2007. An overview of the epidemiology of avian influenza. Vaccine 25(30):5637-5644. <http://dx.doi.org/10.1016/j.vaccine.2006.10.051> $<$ PMid:17126960>

Araujo J., Azevedo Júnior S.M., Gaidet N., Hurtado R.F., Walker D., Thomazelli L.M., Ometto T., Seixas M.M.M., Rodrigues R., Galindo D.B., Silva A.C.S., Rodrigues A.M.M., Bomfim L.L., Mota M.A., Larrazábal M.E., Branco J.O., Serafini P., Neto I.S., Franks J., Webby R.J., Webster R.G. \& Durigon E.L. 2014. Avian influenza virus (H11N9) in migratory shorebirds wintering in the Amazon Region, Brazil. PLoS One 9(10):e110141. <http://dx.doi. org/10.1371/journal.pone.0110141><PMid:25329399>

Bäyon-Auboyer M.H., Jestin V., Toquin D., Cherbonnel M. \& Eterradossi N. 1999. Comparison of F-, G- and N-based RT-PCR protocols with conventional virological procedures for the detection and typing of turkey rhinotracheitis virus. Arch. Virol. 144(6):1091-1109. <http://dx.doi.org/10.1007/ s007050050572><PMid:10446646>

Bäyon-Auboyer M.-H., Arnauld C., Eterradossi N. \& Toquin D. 2000. Nucleotide sequences of the $\mathrm{F}, \mathrm{L}$ and $\mathrm{G}$ protein genes of two non-A/non-B avian pneumoviruses (APV) reveal a novel APV subgroup. J. Gen. Virol. 81(Pt 11):2723-2733. <http://dx.doi.org/10.1099/0022-1317-81-11-2723> <PMid:11038385>

Bennett R.S., Mccomb B., Shin H.J., Njenga M.K., Nagaraja K.V. \& Halvorson D.A. 2002. Detection of avian pneumovirus in wild Canada (Branta canadensis) and blue-winged teal (Anas discors) geese. Avian Dis. 46(4):1025-1029. <http://dx.doi.org/10.1637/0005-2086(2002)046[1025:DOAPIW]2.0. CO;2><PMid:12495069>

Bennett R.S., Nezworski J., Velayudhan B.T., Nagaraja K.V., Zeman D.H., Dyer N., Graham T., Lauer D.C., Njenga M.K. \& Halvorson D.A. 2004. Evidence of avian pneumovirus spread beyond Minnesota among wild and domestic birds in central North America. Avian Dis. 48(4):902-908. <http://dx.doi. org/10.1637/7208-051804R><PMid:15666873>

Cadman H.F., Kelly P.J., Zhou R., Davelaar F. \& Mason P.R. 1994. A serosurvey using enzyme-linked immunosorbent assay for antibodies against poultry pathogens in ostriches (Struthio camelus) from Zimbabwe. Avian Dis. 38(3):621-625. <http://dx.doi.org/10.2307/1592088><PMid:7832718>

Catelli E., Lupini C., Listorti V., Marziali A., De Matteo P., Naylor C.J. \& Cecchinato M. 2012. The pigeon (Columba livia) is not sensitive to Avian Metapneumovirus subtype $B$ and does not play any role in virus spread in experimental conditions. VII International Symposium on Avian Corona and Pneumovirus and Complicating Pathogens, Rauischholzhausen, Germany, p.285-291.

Cha R.M., Yu Q. \& Zsak L. 2013. The pathogenicity of avian metapneumovirus subtype C wild bird isolates in domestic turkeys. J. Virol. 10:1-8. <PMid:23363433>

Cook J.K. 2000. Avian pneumovirus infections of turkeys and chickens. Vet. J. 160(2):118-125. <http://dx.doi.org/10.1016/S1090-0233(00)90486-6> <PMid:10985803>

Cook J.K.A., Ellis M.M. \& Huggins M.B. 1991. The pathogenesis of turkey rhinotracheitis virus in Turkey poults inoculated with the virus alone or together with two strains of bacteria. Avian Pathol. 20(1):155-166. <http://dx.doi.org/10.1080/03079459108418750> <PMid:18680008>

Felippe P.A., Silva L.H., Santos M.B., Sakata S.T. \& Arns C.W. 2011. Detection of and phylogenetic studies with avian metapneumovirus recovered from feral pigeons and wild birds in Brazil. Avian Pathol. 40(5):445-452. <http://dx.doi.org/10.1080/03079457.2011.596812><PMid:21777083>

Gharaibeh S. \& Shamoun M. 2012. Avian metapneumovirus subtype B experimental infection and tissue distribution in chickens, sparrows and pigeons. Vet. Pathol. 49(4):704-709. <http://dx.doi.org/10.1177/0300985811402845> <PMid:21527377>

Hall T.A. 1999. BioEdit: a user-friendly biological sequence alignment editor and analysis program for Windows 95/98/NT. Nucleic Acids Symp. Ser. 41:95-98.

Jardine C.M., Parmley E.J., Buchanan T., Nituch L. \& Ojkic D. 2018. Avian metapneumovirus subtype $\mathrm{C}$ in Wild Waterfowl in Ontario, Canada. Transbound Emerg. Dis. 65(4):1098-1102. <http://dx.doi.org/10.1111/ tbed.12832><PMid:29457370>

Jones R.C. 1996. Avian pneumovirus infection: questions still unanswered. Avian Pathol. 25(4):639-648. <http://dx.doi.org/10.1080/03079459608419171> <PMid:18645888>

Jones R.C. \& Rautenschlein S. 2013. Avian metapneumovirus, p.125-138. In: Swayne D.E., Glisson J.R., McDougald L.R., Nolan L.K., Suarez D.L. \& Nair V. (Eds), Diseases of Poultry. 13th. Ames, Iowa.

Juhasz K. \& Easton A.J. 1994. Extensive sequence variation in the attachment (G) protein gene of avian pneumovirus: evidence for two distinct subgroups. J. Gen. Virol. 75(Pt 11):2873-2880. <http://dx.doi.org/10.1099/00221317-75-11-2873><PMid:7964599>

Kimura M. 1980. A simple method for estimating evolutionary rate of base substitutions through comparative studies of nucleotide sequences. J. Mol. Evol. 16(2):111-120. <http://dx.doi.org/10.1007/BF01731581> $<$ PMid:7463489>

Kumar S., Stecher G. \& Tamura K. 2016. MEGA7: molecular evolutionary genetics analysis version 7.0 for bigger datasets. Mol. Biol. Evol. 33(7):18701874.<http://dx.doi.org/10.1093/molbev/msw054><PMid:27004904> 
Lee E.H., Song M.S., Shin J.Y., Lee Y.M., Kim C.J., Lee Y.S., Kim H. \& Choi Y.K. 2007. Genetic characterization of avian metapneumovirus subtype $C$ isolated from pheasants in a live bird market. Virus Res. 128(1/2):18-25. <http://dx.doi.org/10.1016/j.virusres.2007.03.029><PMid:17485129>

Olsen B., Munster V.J., Wallensten A., Waldenström J., Osterhaus A.D.M.E. \& Fouchier R.A. 2006. Global patterns of influenza A virus in wild birds. Nature 312(5772):384-388. <PMid:16627734>

Seal B.S. 1998. Matrix protein gene nucleotide and predicted amino acid sequence demonstrate that the first US avian pneumovirus isolate is distinct from European strains. Virus Res. 58(1/2):45-52.<http://dx.doi. org/10.1016/S0168-1702(98)00098-7> <PMid:9879761>

Shin H.J., Njenga M.K., Mccomb B., Halvorson D.A. \& Nagaraja K.V. 2000. Avian pneumovirus (APV) RNA from wild and sentinel birds in the United States has genetic homology with RNA from APV isolates from domestic turkeys. J. Clin. Microbiol. 38(11):4282-4284. <PMid:11060113>

Shin H.J., Cameron K.T., Jacobs J.A., Turpin E.A., Halvorson D.A., Goyal S.M., Nagaraja K.V., Kumar M.C., Lauer D.C., Seal B.S. \& Njenga M.K. 2002. Molecular epidemiology of subgroup $C$ avian pneumoviruses isolated in the United States and comparison with subgroup A and B viruses. J. Clin. Microbiol. 40(5):1687-1693. <http://dx.doi.org/10.1128/JCM.40.5.16871693.2002><PMid:11980943>

Spackman E., Pedersen J.C., Mckinley E.T. \& Gelb Junior J. 2013. Optimal specimen collection and transport methods for the detection of avian influenza virus and Newcastle disease virus. BMC Vet. Res. 9(1):35. <http:// dx.doi.org/10.1186/1746-6148-9-35> <PMid:23432911>
Stuart J.C. 1989. Rhinotracheitis: turkey rhinotracheitis (TRT) in Great Britain. Recent Advances in Turkey Science, 21th Poultry Science Symposium Series, London, p.217-224.

Sun S., Chen F., Cao S., Liu J., Lei W., Li G., Song Y., Lu J., Liu C., Qin J. \& Li H. 2014. Isolation and characterization of a subtype $C$ avian metapneumovirus circulating in Muscovy ducks in China. Vet. Res. 45:74. <PMid:25060776>

Thompson J.D., Higgins D.G. \& Gibson T.J. 1994. CLUSTAL W: improving the sensitivity of progressive multiple sequence alignment through sequence weighting, position-specific gap penalties and weight matrix choice. Nucleic Acids Res. 22(22):4673-4680. <http://dx.doi.org/10.1093/ nar/22.22.4673><PMid:7984417>

Toquin D., Bayon-Auboyer M.H., Eterradossi N., Jestin V. \& Morin H. 1999. Isolation of a pneumovirus from a Muscovy duck. Vet. Rec. 145(23):680. $<$ PMid:25705778>

Turpin E.A., Stallknecht D.E., Slemons R.D., Zsak L. \& Swayne D.E. 2008. Evidence of avian metapneumovirus subtype $\mathrm{C}$ infection of wild birds in Georgia, South Carolina, Arkansas and Ohio, USA. Avian Pathol. 37(3):343-351. <http://dx.doi.org/10.1080/03079450802068566> <PMid:18568663>

Van Boheemen S., Bestebroer T.M., Verhagen J.H., Osterhaus A.D., Pas S.D., Herfst S. \& Fouchier R.A. 2012. A family-wide RT-PCR assay for detection of paramyxoviruses and application to a large-scale surveillance study. PLoS One 7(4):e34961. <http://dx.doi.org/10.1371/journal.pone.0034961> $<$ PMid:22496880> 